\title{
Effects of Resource Partitioning on the Home Range of Feral House Mice
}

Lee Ann HACKMANN, Paula A. WUEST \& Gary W. BARRETT

Hackmann L. A., Wuest P. A. \& Barrett G. W., 1980: Effects of resource partitioning on the home range of feral house mice. Acta theriol., 25, 35: 425-430 [With 1 Table \& 1 Figs.].

This study examined the effects of resource partitioning on the home range of the house mouse (Mus musculus Linnaeus, 1758). Home range was calculated with the method developed to capture asymptotic square area. Results revealed that resource partitioning between centralized versus decentralized grids did not differ significantly. Mean home range of males, however, was found to be significantly larger that mean home range of females. The significance of these findings is discussed.

[Dept. Zool.-Institute Env. Sci., Miami Univ., Oxford, Ohio 45056, U.S.A.].

\section{INTRODUCTION}

Home range has been defined by B u r (1943) as that area an animal travels during its normal activities (e.g., searching for food). Numerous investigators have developed methods to quantify home range (e.g., Hayne, 1949; C a lhoun \& Cosby, 1958; M etz gar \& Sheldon, 1974). The concept of home range, however, is a dynamic concept and the quantitative computation of its functional area is based on such factors as habitat structure, resource partitioning, behavioral interactions and changes in population dynamics. Many of these characteristics are encompassed in the method for computing home range as developed by Metzgar \& Sheldon (1974). This method was used in the present study to calculate home range for feral house mouse (Mus musculus Linnaeus, 1758) populations contained in contrasting resource partitioned plots.

The purpose of this study was to measure and evaluate the effects of resource partitioning (i.e., food location) on the home range of feral house mice living under natural habitat conditions. We hypothesized that animals functioning within centralized grids would exhibit larger home ranges than those within decentralized grids due to increased food gathering activities and intraspecific behavioral interactions. 


\section{MATERIALS AND METHODS}

\subsection{Experimental Design}

This study was conducted at the Miami University Ecology Research Center, Oxford, Ohio, U.S.A. The study area consisted of eight adjacent 0.1-ha plo:s (grids) enclosed by 1.22 by 3.05 meter sheets of 20 -gauge galvanized steel (Fig. 1). These enclosure walls prevented the intergrid movements of house mouse populations. Enclosures of this kind have been previously described (B a r r e t, 1963; $\mathrm{Stueck} \& \mathrm{Barret} t$, 1978). All grids were planted with a homogeneous mixture of grasses. The vegetational composition and maintenance of these grids have been described in detail by $S$ tueck \& Barrett (1978).

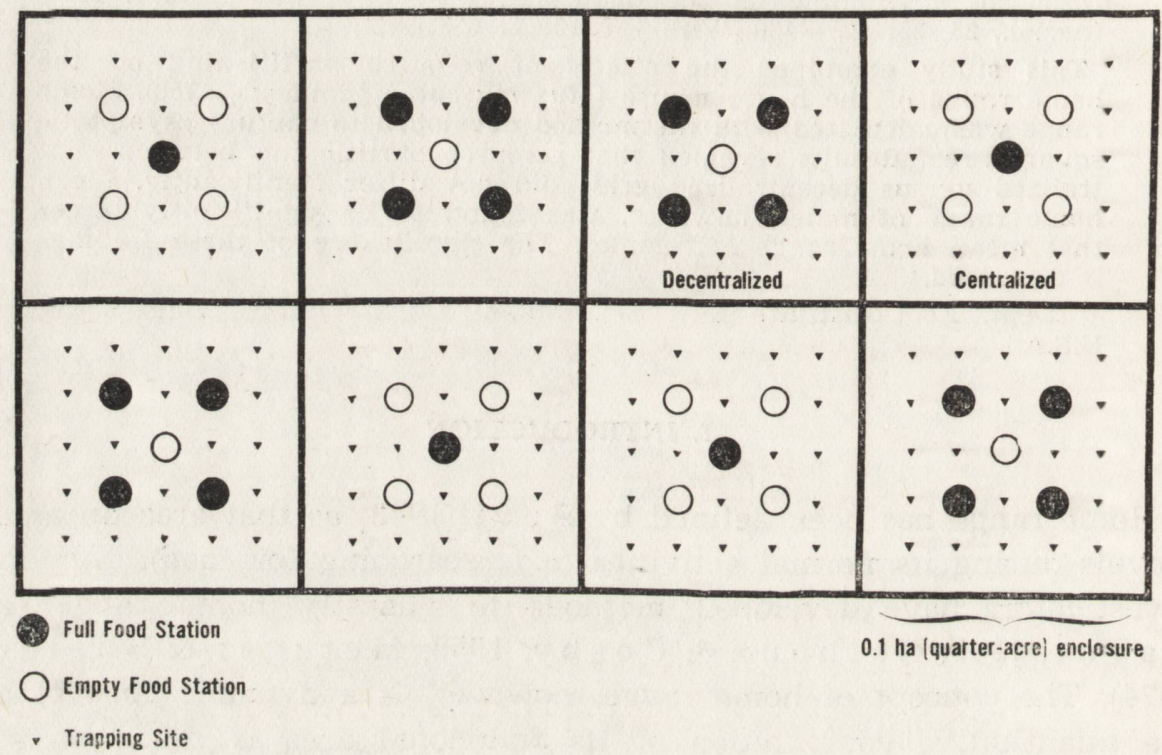

Fig. 1. Experimental design of the eight 0.1-ha small mammal grids (modified after Stueck \& Barrett, 1978).

A homogeneous habitat was established for each grid population. Each grid contained five food depots. These food depot stations are similar to those described by $\mathrm{News}$ ome (1969). The grids varied only in the pattern of the distribution of the food resources (Fig. 1). Four of the grids, referred to as centralized grids, consisted of a single centralized depot, whereas the remaining four grids, referred to as decentralized grids, consisted of four evenly-spaced peripheral food depots. Each grid was supplied weekly with preweighed ears of corn. Forty Sherman-type live-traps, which were suspended from metal trapping poles when not in use, were spaced 6.4 meters apart within each square grid and 3.7 meters from the sides of the steel enclosure. Four live-traps were also uniformly spaced around each of the five food stations in each grid.

Each grid was stocked on 6 June 1975 with four pairs of adult feral house mice and allowed to populate the grids until late December 1975. The house 
mice were censused by the calendar of catches method (Pe trusewicz \& Andrzejewski, 1962). Live-trapping was conducted in ali grids weekly, except from September to December when it was necessary to trap twice weekly to sufficiently census the increasing populations. Traps were baited with peanut butter in the evening and checked the next morning. Captive animals were sexed, weighed, checked for reproductive condition, marked by toe-clipping, and the site of capture recorded.

\subsection{Data Analysis}

The home range areas of individual mice were calculated with the Metzgar \& Sheldon (1974) index of home range. This method is derived from the assumption that, as the capture locations increase, the area of observation increases asymptotically. The asymptote, which represents the total area within which the animal can be observed, can be computed despite the sample size of the capture data. Our data were limited to those animals with a minimum of ten capture locations. This limitation has been used in other studies ( $\mathrm{M} \mathrm{a} \mathrm{z}$ a et al., 1973; Metzgar \& Sheldon, 1974).

The square home range area was calculated by multiplying the index of home range $S_{00}$ (the number of locations an animal would be recorded after an infinite number of captures) by the square of the distance between the traps (i.e., Area $\left.=S_{00} \times(6.4)^{2}\right)$. This derivation of home range is in conjunction with the exclusive boundary strip method (Stickel, 1954). The index, $S_{00}$, can be computed as $S_{00}=1 /\left(1-e^{-k}\right)$, where $e^{-k}=\Sigma\left[S_{c}\left(S_{c+1}-1\right)\right] \Sigma S_{c}^{2}$, and the variables $c=$ number of captures per individual, $S_{c}=$ number of distinct locations at which the animal has been recorded after $c$ captures, and $S_{c+1}=$ number of locations after one additional capture.

\section{RESULTS}

The effects of sex and grid type on the home range of the Mus musculus were tested with a factorial arrangement of a completely random design analysis of variance. There were no significant differences between the home ranges of the mice in the centralized and decentralized grids $(F=.66 ; \mathrm{df}=1,48 ; p>0.98)$. Nor was there an interaction between grid type and sex $(F=1.37$, df $=1,48, p>0.20)$. However, there was a significant difference in the mean observed home range of males and females $(F=13.9 ; \mathrm{df}=1,48 ; \quad p<0.01)$. Sexual differences were also found in the male and female activity centers (i.e., average of all capture locations) in the separate grid types. No more than two males had an activity center within a 3.2-meter radius of a food station in contrast to the females which were found in groups of two or more.

The mean home ranges observed in the different sex and grid types are shown in Tab. 1. Data included all mice with at least ten recaptures. 


\section{DISCUSSION}

The resource architecture of a habitat plays an important role in the regulation of the demographic and functional factors operating in feral house mouse populations. The concept of home range was used as an investigative tool to examine the effects of resource partitioning on the movement patterns established in Mus musculus populations. An animal's home range encompasses its resource and habitat requirements and is therefore modified according to resource availability ( $\mathrm{M} \mathrm{a} \mathrm{z} \mathrm{a}$ et al., 1973). In the present study, the location of the food source was manipulated in grids of homogeneous structural complexity. Results indicate that resource partitioning did not significantly affect home range size established in the two grid-types. A significant difference was found, however, in the mean range between males and females.

Table 1

Home range sizes calculated for grid-type, sex, and the interaction of grid-type and sex.

\begin{tabular}{lcc}
\hline Group & $\begin{array}{c}\text { Number of } \\
\text { animals }\end{array}$ & $\begin{array}{c}\text { Mean home range } \\
\left(\mathrm{m}^{2} \pm \mathrm{S} . \mathrm{D} .\right)\end{array}$ \\
\hline Centralized female & 17 & $291 \pm 101$ \\
Centralized male & 8 & $380 \pm 107$ \\
Decentralized female & 18 & $241 \pm 114$ \\
Decentralized male & 9 & $417 \pm 172$ \\
Female & 35 & $261 \pm 107$ \\
Male & 17 & $404 \pm 141$ \\
Centralized & 25 & $312 \pm 107$ \\
Decentralized & 27 & $302 \pm 156$ \\
\hline
\end{tabular}

Resource partitioning has been found to exert an effect on the social structure and population dynamics established within feral mouse populations (N oyes, 1977; S t u e ck \& B a r rett, 1978). In centralized grids, food availability was reduced, forming rigid social hierarchies which in turn reduced the carrying capacity. Stueck \& Barrett (1978) reported a carrying capacity of 20 individuals in the centralized grid as compared to a carrying capacity of 30 individuals in the decentralized grid. The populations in the decentralized grid possessed a more flexible social structure and were able to maintain a higher carrying capacity. During high population densities, a higher degree of overlap is tolerated in adjacent home ranges ( $\mathrm{M} \mathrm{a} \mathrm{z} \mathrm{a} \mathrm{et} \mathrm{al.,} \mathrm{1973).} \mathrm{M} \mathrm{et} \mathrm{z} \mathrm{g} \mathrm{a} \mathrm{r}$ (1979) also found overlapping home ranges to have maximized the acquisition of resources and of successful matings. This tolerance of broad home range overlaps may have obscured the spatial relationships 
that were influenced by the resource partitioning in the decentralized grid.

The significant difference $(\mu<0.05)$ between the home ranges of males and females is supportive of the different functional characteristics of the sexes within a population. Other studies have shown this sex-related difference in home range size ( $\mathrm{H}$ a r e stad \& Bunnell, 1979; C r a n ford, 1977; M a z a et al., 1973). Differences between male and female home range size have been attributed to weight differences (H a restad \& Bunnell, 1979). A recent study by B owers \& $\mathrm{Smith}$ (1979) indicated that females occupy the better habitat and have smaller home ranges. This specific habitat selection relates to the high energy expenditure of the female in the nurturing and supporting of her young. S t u e ck \& B a r r e t t (1978) found significantly heavier adrenal gland weights in the prereproductive and young adult females in both grid types. This finding indicated the presence of stress which may be attributed to the intraspecific competition between the females for the acquisition of the better habitats. In a homogeneous habitat, the resources may be partitioned between the sexes by different foraging strategies. The female would acquire the optimal area near the resource whereas the male would require a larger surrounding area in order to fulfill his physiological requirements.

In summary, the unexpectedly high mean home ranges of the decentralized grid may be explained by the flexible nature of the social structure and by the dispersal patterns established in the more heavily populated grid. The interaction of behavioral, bioenergetic, and demographic factors in relation to the habitat architecture seems to play an important role in the population dynamics of the feral house mouse, Mus musculus.

Acknowledgements: The authors wish to thank Dr. John Skillings for statistical advice and Mrs. Ruth McLeod for manuscript preparation. Thanks are also extended to Debbie Leach, Robert Noyes, and Karen Stueck for field assistance. This study was partially supported by a Miami University Faculty Research Grant to Dr. Gary W. Barrett.

\section{REFERENCES}

1. Barrett G. W., 1968: The effects on an acute insecticide stress on a semienclosed grassland ecosystem. Ecology, 49: 1019-1035.

2. B owers M. A. \& Smith D. H., 1979: Differential habitat utilization by sexes of the deermouse, Peromyscus maniculatus. Ecology, 60: 869-875.

3. Burt W. H., 1943: Territoriality and home range. J. Mammal., 24; 346-352.

4. Calhoun J. B. \& Cosby J. U., 1958: Calculation of home range and density of small mammals. U. S. Public Health Monogr., 55: 1-24.

5. Cranford J. A., 1977: Home range and habitat utilization by Neotoma fuscipes as determined by radiotelemetry. J. Mammal., 58: 165-172. 
6. Harestad A. S. \& Bunnel1 F. L., 1979: Home range and body weight-a reevaluation. Ecology, 60: 389-402.

7. Hayne D. W., 1949: Calculation of size of home range. J. Mammal., 30: $1-18$.

8. Maza B. G., French N. R. \& Aschwanden A. P., 1973: Home range dynamics in a population of heteromyid rodents. J. Mammal., 54: 405-425.

9. Metzgar L. H. \& Sheldon A. L., 1974: An index of home range size. J. Wildlife Manage., 38: 546-551.

10. Metzgar L. H., 1979: Dispersion patterns in a Peromyscus population. J. Mammal., 60: 129-145.

11. News ome A., 1969: A population study of house mice permanently inhabiting a reed-bed in South Australia. J. Anim. Ecol., 38: 361-377.

12. Noyes R. F., 1977: Social structure of feral house mouse (Mus musculus L.) populations with respect to food depots. Masters thesis, Science Library, Miami University, Oxford, Ohio, $48 \mathrm{pp}$.

13. PetrusewiczK. \& Andrzejewski R., 1962: Natural history of a freeliving population of house mice (Mus musculus Linnaeus) with particular reference to groupings within the population. Ecol. Pol., Ser. A, 10: 85-122.

14. Stickel L. F., 1954: A comparison of certain methods of measuring ranges of small mammals. J. Mammal., 35: 1-15.

15. Stueck K. L. \& Barrett G. W., 1978: Effects of resource partitioning on the population dynamics and energy utilization strategies of feral house mice (Mus musculus) populations under experimental field conditions. Ecology, 59: $539-551$.

Accepted, June 23, 1980.

Lee Ann HACKMANN, Paula A. WUEST i Gary W. BARRETT

\section{WŁAŚCIWOSCI SRODOWISKA A AREAŁ OSOBNICZY MYSZY DOMOWEJ}

\section{Streszczenie}

Badano wpływ zróżnicowania środowiska (dostępności pokarmu) na areał osobniczy u dziko żyjących myszy domowych. Pokarm był wykładany w różny sposób, na ośmiu działkach, każda o powierzchni 0,1 ha (Ryc. 1). Wykazano, że nie powoduje to zmiany arealu osobniczego u myszy, choć areał ten jest istotnie większy u samców niż u samic (Tabela 1). 